\title{
Diverging Trends in the Socialist Constitutionalism of the People's Republic of China and Socialist Republic of Vietnam
}

\author{
FU Hualing \& Jason BUHI * \\ The University of Hong Kong
}

I. $\quad$ Introduction

The People's Republic of China and Socialist Republic of Vietnam are probably the best reference points for each other in comparative studies of socialist constitutionalism, not just for their extensive similarities, but also their growing differences. For at least a decade, and especially since $2011,{ }^{1}$ the two East Asian Party-states have been pursuing increasingly distinct paths towards the future. Although history records that Vietnam has taken important governance cues from China for centuries, ${ }^{2}$ a discernable pattern exists whereby some of Vietnam's more independent moves occur during periods of tension with its neighbor to the north. ${ }^{3}$

We seem to be at such a geopolitically-inspired crossroads right now, as China

\footnotetext{
* FU Hualing, Professor of Law, University of Hong Kong Faculty of Law; Jason BUHI, Ph.D. Candidate in Constitutional Law at the University of Hong Kong and C.V. Starr Lecturer, Peking University School of Transnational Law (Shenzhen). The authors would like to thank Bui Ngoc Soon, John Gillespie, Keith Hand, Andrew Harding, Pip Nicholson, and Wang Chenguang for their comments on the earlier versions of this paper.

${ }^{1}$ We assert that China has been growing more insular since the $18^{\text {th }}$ Party Congress in 2012, while Vietnam has been trending more open since its $11^{\text {th }}$ Party Congress in 2011.

${ }^{2}$ China dominated Vietnam for much of the period from 112 BC to 939AD, and the Chinese influence continued with varying intensity to the present era. For example, the $19^{\text {th }}$ Century Nguyen Dynasty's Gia Long Code was heavily based on the Qing Code. Later, Chinese advisers shaped the stance of the Communist Party of Indochina during the 1940s. See John Gillespie and Albert Chen, Legal Reforms in China and Vietnam: A Comparison of Asian Communist Regimes (Routledge Press, 2010), various historical notes compiled from pages 3-6; see also Dosch \& Vuving, The Impact of China on Governance Structures in Vietnam (Bonn: German Development Institute, 2008).

${ }^{3}$ Vietnam, like China, attempted a near-wholesale importation of the Soviet political-legal system, but remained closer to Moscow upon the Sino-Soviet split in 1968. Relations deteriorated as the countries fought a border war in 1979. Deference reappeared in the mid-1980s as Vietnam's doi moi reforms aligned Vietnam with China's reform policies, but the Vietnamese counterbalanced that with more internationalist initatives after 1989, as many major laws were borrowed from or inspired by multilateral institutions in the 1990s. Id. (Gillespie and Chen) pp. 7-8.
} 
pursues aggressive territorial claims in waters off the Vietnam coast. ${ }^{4}$

Despite of their significant differences in size, population, and economic scale, the two systems invite comparison because they share common cultural (Confucian) ${ }^{5}$ and political (Soviet) ${ }^{6}$ origins. Both state apparatuses are subordinate to the leadership of a communist party whose supremacy is entrenched in the national constitution. Both claim to be committed to building a socialist rule of law that offers protection of human rights, although the substance differs greatly from Western expectations. ${ }^{7}$ Both have been experiencing rapid socioeconomic transformations after liberalizing policies under the banner of developing a socialist market economy. ${ }^{8}$

\footnotetext{
${ }^{4}$ Whereas the Preamble of the Vietnamese Constitution of 1992 twice thanked "the precious assistance of friends across the world, especially of the socialist and neighboring countries" (emphasis added) in achieving revolutionary victories, the "especially" clause was dropped from the new Constitution of 2013. Similar language was removed from new Article 12 (old Article 14) describing the substantive bases of Vietnam's foreign policy. Indeed, the HYSY 981 oil-rig incident invited speculation that Vietnam will revisit its "Three Nos" defense policy (i.e., having no formal military alliances, not allowing any foreign military bases on Vietnamese territory, and not relying on other countries in combat operations). See Ankit Panda, "After HYSY-981: A U.S.-Vietnam Alliance?" The Diplomat, 22 July 2014, available at http://thediplomat.com/2014/07/after-hysy-981 -a-u-s-vietnam-alliance/ (last visited 16 Oct 2015).

5 Bui Ngoc Son, “The Confucian Foundations of Ho Chi Minh's Vision of Government,” Journal of Oriental Studies 46 (1) (2013): 35-59 (co-published by University of Hong Kong and Stanford University).

${ }^{6}$ The Preamble of the 1982 Constitution explicitly entrenches the leadership of the CCP and, according to Article 1, China remains a socialist country practicing "democratic dictatorship" based on the alliance of workers and peasants. The Preamble of the 2013 Vietnamese Constitution notes the leadership of the VCP, while Article 4 declares that the VCP, "acting upon the Marxist-Leninist doctrine and Ho Chi Minh's thought, is the leading force of the State and society." 2013 Vietnam Constitution, translation available at http://www.constitutionnet.org/files/tranlation_of_ vietnams_new_constitution_enuk_2.pdf (last visited 16 Oct 2015).

7 See, e.g., Albert H.Y. Chen, "Conclusion: Comparative reflections on human rights in Asia," in Randall Peerenboom et al. (eds.), Human Rights in Asia (London: Routledge, 2006); Sonya Sceats and Shaun Breslin, "China's Indirect Impact on the International Human Rights System," in China and the International Human Rights System, Chp. 5, pp. 41-45 (London: Chatham House, 2012); "Human Rights Watch World Report: Vietnam 2013," available at https://www.hrw.org/world-report/2013/country-chapters/vietnam (last visited 17 Oct 2015).

${ }^{8}$ Both are middle income countries, although China is at the higher-middle end of the per capita income scale (USD 7,589) while Vietnam is at the lower-middle end (USD 2052). In terms of GDP per capita (nominal), China ranked 78/184 in 2014 with USD 7,589 per capita; and Vietnam's was USD 2,052, ranked 132/184. To put this in perspective, Vietnam in 2014 was where China was in 2006. IMF ranking available at http://www.indexmundi.com/facts/indicators/NY.GDP.PCAP.CD/compare?country $=$ cn\#country=cn:vnm (last visited 16 Oct 2015).

Meanwhile, the United Nations Development Program's (UNDP) Human Development Index (HDI) provides another apt comparison. In 2013, China was ranked as a high development country with a HDI score of .719 , while Vietnam was a middle development country with a score of .638. Once again, Vietnam in 2013 was about where China was in 2004/2005 in terms of HDI. UNDP HDI Index
} 
Noting these similarities, several comparative studies have been undertaken in recent years, ${ }^{9}$ but the field lies outside the mainstream of international constitutional discourse and is therefore still open to development. Conventional liberal criticism of constitutional law studies regarding Leninist states is that those orders lack constitutionalism, i.e., the text does not outline and establish a system that functions to constrain the real political power of (or behind) the state, especially through an independent judiciary. ${ }^{10}$ Thus described, the constitution's only operative provisions are the decrees justifying the exercise of absolute political power by the ruling party; all other provisions - especially those involving individual liberties - are merely irrelevant "window dressing." ineffective and inconsequential. Yet these critiques cannot explain why such meaningless constitutional provisions are robustly debated and frequently resorted to, with varying degrees of effectiveness, by aggrieved parties both through the courts and on the streets, as discussed below.

Many argue that socialist constitutions are, at least, aspirational, ${ }^{12}$ and history demonstrates that once inspired there is little the peoples of China or Vietnam cannot

available at http://hdr.undp.org/en/content/human-development-index-hdi (last visited 16 Oct 2015).

${ }^{9}$ See, for example, Gillespie and Chen, Legal Reforms in China and Vietnam: A Comparison of Asian Communist Regimes (Routledge Law in Asia, 2010); John Gillespie and Pip Nicholson, Asian Socialism and Legal Change: The Dynamics of Vietnamese and Chinese Reform. (Canberra: Asia Pacific Press, 2005); Bui Ncqc Son, "The Discourse of Constitutional Review in Vietnam" 9 Journal of Comparative Law 175-205; Mark Sidel, Law and Society in Vietnam: The Transition from Socialism in Comparative Perspective (Cambridge University Press, 2008); Dosch \& Vuving, The Impact of China on Governance Structures in Vietnam (Bonn: German Development Institute, 2008).

10 Albert H.Y. Chen, "The Achievement of Constitutionalism in Asia: Moving Beyond "Constitution without Constitutionalism," in Constitutionalism in Asia in the Early Twenty-First Century (Cambridge University Press, 2014).

${ }^{11}$ Tony Saich, Governance and Politics of China, $3^{\text {rd }}$ Ed. (Parlgrave Macmillian, 2010), 148.

12 This characterization has been around for many years. See, for example, The Constitutions of the Communist World, William B. Simons (ed.), (Germantown, MD, USA: Sijthoff \& Noordhoff, 1980), p. Xv: "The constitutions of the communist world have always been used for internal as well as external consumption - to proclaim what has been achieved and to lay down the program of what is still to be accomplished." He Weifang, Stephanie Balme and Michael Dowdle, among others, point out that a significant part of the 1982 Chinese Constitution declares goals to be achieved in the future, including a system of democratic political representation as well as a wide range of political, social and economic rights. Balme and Dowdle refer to China's constitutionalism as "development potential, not developmental accomplishment," in Building Constitutionalism in China (Palgrave, 2010), 10. 
achieve. The Party-states, having codified normative rights, face credibility crises if they violate the peoples' expectations by ignoring those undertakings for too long. Indeed, constitutional interpretation, enforcement, and/or reform sometimes legitimately occur through alternative processes known as either "political constitutionalism" (wherein political mechanisms such as legislative processes assume and manage constitutional enforcement), ${ }^{13}$ or "popular" or "civic" constitutionalism (wherein citizens spontaneously assert ownership over constitutional interpretation and compel a dialogue and a settlement with the state on matters relating to constitutional rights). ${ }^{14}$ While the former can be used to capture popular demands within the authoritarian system, the latter may be more worrisome to authoritarian rulers, as the spontaneous demand for constitutional rights is "gain[ing] new cohesion and momentum,"15 demonstrating a nascent constitutional awareness among the public outside of the Party-states' master plan. ${ }^{16}$ Inspired citizens are increasingly usurping judicial roles by interpreting and implementing constitutional rights through online mobilizations, peaceful vigils, religious ceremonies, labor

13 See Chen Duanhong, "The People Must be Present" (Ren Min Bi Dei Chu Chang), in Constituent Power and Fundamental Law (Zhi Xian Quan Yu Gen Ben Fa), (Beijing: China Legal Publishing House), 46-110; Jiang Shigong (2010) "Written and Unwritten Constitution: A New Approach to the Study of Constitutional Government in China," Modern China 36(1): 12-46.

14 Bruce Ackerman, We the People: Foundations (Harvard University Press, 1993); John E. Finn, "The Civic Constitution: Some Preliminaries" in Barber and George (eds.) Constitutional Politics: Essays on Constitution Making, Maintenance, and Change (Princeton University Press, 2001), 44; Larry Kramer, The People Themselves: Popular Constitutionalism and Judicial Review (Oxford University Press, 2004); Richard Bellamy, Political Constitutionalism: A Republican Defense of the Constitutionality of Democracy (Cambridge University Press, 2007); Bui Ngoc Son and Pip Nicholson, Activism and Popular Constitutionalism in Contemporary Vietnam, Law \& Social Inquiry Law (2016); and Mark Tushnet, Popular Constitutionalism as Political Law, 81 Chicago-Kent L. Rev. 991 (2006); Zhang Qianfan, A Constitution without Constitutionalism? The Paths of Constitutional Development in China, 8:4 Int'1 J. of Constitutional Law 950 (2010).

15 Hand, Resolving Constitutional Disputes in Contemporary China, 7 U. Penn East Asia L. Rev 51 (2011), 65-6.

${ }^{16}$ See Stephanie Balme, "China's Constitutional Research and Teaching: A State of the Art," in Building Constitutionalism in China (Stephanie Balme and Michael W. Dowdle eds., 2009), 107; Hand, "Citizens Engage the Constitution: The Sun Zhigang Incident and Constitutional Review Proposals in the People's Republic of China," Id. at 221. See also Stephanie Balme, The Judicialisation of Politics and the Politicisation of the Judicary (1978-2005), 5 Global Jurist Frontiers 1 (2005); Randall Peerenboom, Law and Development of Constitutional Democracy: Problem or Paradigm?, 19 Colum. J. Asian L. 185, 204 (2005). 
strikes and street actions. ${ }^{17}$ Such resilient demands have made constitutional supremacy a subject of lively debate, ${ }^{18}$ with the positive potential of generating more healthy dialogue between Party-state and society. Indeed, a diverse range of legal and accommodative approaches are now being deployed. ${ }^{19}$ As such, if constitutional studies concern the distribution and exercise of political power, then research on the Chinese and Vietnamese constitutions must venture into a "results-oriented pragmatic approach." 20 The failure to explore such avenues is fatal to an academic understanding of different national governance schemes, comparative scholarship generally and, specifically, to the aspirations of citizens and reformers in socialist states who seek to develop ties to mainstream constitutional discourse.

This chapter provides an overview to comparative study of Sino-Vietnamese comparative constitutionalism by exploring the bases of three core, substantive pillars of socialist constitutionalism through the Sino-Vietnamese comparison: insistence on Party leadership, reliance on socialist rule of law, and adaptation to populism. After considering several examples of how constitutional rules are currently operating through political and popular constitutionalism in all three areas, we conclude that Vietnam is presently moving in a direction offering more prospects for convergence with international norms ${ }^{21}$ as the current Vietnamese Party-state is relatively less

${ }^{17}$ Hand, Resolving Constitutional Disputes, at 92, also citing Carl Minzner, Xinfang: Alternative to Formal Chinese Legal Institutions, 42 Stan. J. Int'l L. 103, 143-45 (2006).

${ }^{18}$ Of course, both China and Vietnam make the controversial assertion that their national constitutions are the supreme law of the land (1982 Chinese Constitution, Art. 5; 2013 Vietnamese Constitution, Arts. 4, 8, 9), but the lack of rigorous judicial enforcement does not necessarily mean the constitution is an empty letter.

19 Judicial enforcement is obviously preferable as it is more transparent, structured and formal; political and popular constitutionalism are both characterized by opacity and informal trade-offs, while popular constitutionalism can be informal or occasionally chaotic. See, for example, Keith Hand, "Constitutionalizing Wukan: The Value of the Constitution outside the Courtroom," 12:3 China Brief (Feb 2012); Carl Minzner, Xinfang: Alternative to Formal Chinese Legal Institutions, 42 Stan. J. Int'1 L. 103, 143-45 (2006).

${ }^{20}$ Peerenboom, The Social Foundations of China's Living Constitution (2010), 41.

21 Some institutional limits on this flirtation are evaluated by Thiem Bui, Liberal Constitutionalism and the Socialist State in an Era of Globalization: An Inquiry into Vietnam's Constitutional Discourse and Power Structures, 5 The Global Studies Journal 2 (2013). 
politically monolithic, more open to the influence of international laws, and more tolerant of civil society than its Chinese counterpart. That being the case, we predict that Vietnam will likely continue to depart from the increasingly insular Chinese model of constitutional development for the foreseeable future.

\section{Leadership of the Communist Parties}

At a foundational level, there have been few structural changes to the authoritarian Chinese and Vietnamese Party-state constitutional orders in spite of the pervasive social and economic reforms of the last three decades. With the exception of the first Vietnamese Constitution of $1946,{ }^{22}$ all of China and Vietnam's post-revolution constitutions (each of which has had five) have enshrined Leninist political supervision. Party leadership is a prime directive consistently entrenched in both the Chinese and Vietnamese national constitutions, clearly declared in their respective Preambles and core text. ${ }^{23}$ The respective Chinese Communist Party (CCP) and the Vietnamese Communist Party (VCP) monopolize political and military power, ${ }^{24}$ institutionalize democratic centralism, and prohibit threatening discourse.

Though Party leadership cannot be changed through any legal means, the organization of that power takes significantly different expressions in China and Vietnam. While decisive and effective implementation characterizes both orders, the

${ }^{22}$ Perhaps this is because that 1946 Constitution represented a synthesis of Western and Ho Chi Minh Thought, calling for a tripartite separate of powers and guaranteeing fundamental rights. David G Marr, Ho Chi Minh's Independence Declaration, in Essays into Vietnamese Pasts (K W Taylor and John K. Whitmore eds.) (Connell University Press, 1995), pp. 221-231.

23 Supra note 4.

${ }^{24}$ Article 4 of the Vietnam Constitution (2013) makes the party the vanguard and representative not only of the Vietnamese working class, but of the whole Vietnamese people and nation, further narrowing the legal space to exercise the right to pluralistic and freely contested elections. Article 65 follows the government lead in enshrining a new legal requirement for Vietnam's armed forces to be absolutely loyal to the Communist Party. 
Vietnamese Party-state is presently more open to constructive debate within the party forum, as evinced by having more diffuse executive authorities and a more competitive selection process for membership in its Central Committee.

Indeed, both nations feature a Party-state that operates on the basis of democratic centralism. This ensures a decisive decision-making process, thus establishing "effective" states in which policy-making and implementation is swift, owing in part to a denial of separation of powers and a lack of mechanisms through which formal checks-and-balances can be exercised. ${ }^{25}$ While these structural deficiencies perpetuate other systemic problems, they need not undercut raw "government effectiveness" which - as defined by international institutions - simply measures whether a regime can implement meaningful change. ${ }^{26}$ Fukuyama forcefully argues that state effectiveness is a necessary condition for successful constitutional and legal reform, as strong leaders in the Confucian tradition are well positioned for nation-building, demonstrated by the cases of South Korea, Japan, Taiwan and Singapore. ${ }^{27}$ Once there is the political will to promote reform, effective states have strong institutions to rely upon and competent bureaucrats to implement programs with a high degree of efficiency. ${ }^{28}$ Accepting that both states have high implementation capacity, ${ }^{29}$ the questions becomes those of political values and will.

25 As the 2014 Decision Concerning Some Major Questions in Comprehensively Promoting the Rule of Law (Zhonggong zhongyang guanyu quanmian tuijin yifa zhiguo ruogan zhongda wenti de jueding) explains, China will not admit any separation of powers and will not tolerate any institution to have a veto on the Party's decisions. English translation and Chinese original available at https://chinacopyrightandmedia.wordpress.com/2014/10/28/ccp-central-committee-decision-concernin g-some-major-questions-in-comprehensively-moving-governing-the-country-according-to-the-law-for ward/ (last visited 17 Oct 2015).

26 The World Bank provides this definition: "Government effectiveness captures perceptions of the quality of public services, the quality of the civil service and the degree of its independence from political pressures, the quality of policy formulation and implementation, and the credibility of the government's commitment to such policies."

${ }^{27}$ Francis Fukuyama, Political Order and Political Decay: From the Industrial Revolution to the Globalisation of Democracy (Profile Books, 2014).

28 "Regardless of the degree of government intervention, the fast-growing economies of East Asia share a common feature: they all possess competent, high-capacity state." Id. at 335.

${ }^{29}$ For instance, the World Bank's Worldwide Governance Indicators (WGI) index measures 
It is perhaps on those bases that several meaningful and consequential differences between the political designs of the two Party-states is emerging. Since the events of 1989, the CCP has since demonstrated a much higher level of concentration of political power in the hands of a smaller number of men, while the VCP has demonstrated signs of political diffusion, splitting into contesting blocs. As a result, the nascent checks-and-balances within the Vietnamese system are more apparent. Former Chinese President $\mathrm{Hu}$ Jintao found the trend so disturbing that he felt compelled to issue an internal Party document:

... criticiz[ing] the Vietnamese authorities for moving "too quickly toward inner-party democracy," even warning that a destabilizing Mikhail Gorbachev-like figure could come to power. The CCP also banned public discussion of Vietnam's reforms, deploying party intellectuals to argue publicly against such a political development in China. ${ }^{30}$

That fear likely emanates from the fact that developments in Vietnam indicate the emergence of more political constitutionalism, as there is more intra-party democracy in the VCP than the CCP.

At the level of elite politics, the commanding heights of Vietnam's Party-state feature a broader policy-making coalition involving more diverse stakeholders in the decision-making process. ${ }^{31}$ This is true in both the executive and legislative arenas.

governance ability via six indicators: voice and accountability; political stability and absence of violence; government effectiveness; regulatory quality; rule of law; and control of corruption. China and Vietnam performed the best in government effectiveness among the six indicators in the 2014 survey. Importantly, China outperformed its "East Asian and Pacific" neighbors in "government effectiveness" while lagging behind in the other five indicators, while Vietnam closely tracked the regional averages. As a lower-middle income country, Vietnam clearly outperformed other similarly situated countries in terms of both "political stability" and "government effectiveness." These assets generate confidence and legitimacy in the durability of the system and hope for its capacity to improve. World Bank Worldwide Governance Indicators, Government Effectiveness, available at http://info.worldbank.org/governance/wgi/index.aspx\#doc (last visited 17 Oct. 2015).

30 Regina Abrami, Edmund Malesky and Yu Zheng, "Vietnam through Chinese Eyes: Divergent Accountability in Single-Party Regimes," citing Gu Sanyue, "Yuenan chule ge 'Deng Xiaoping"” ("There is a Deng Xiaoping in Vietnam"), Blog China, Dec 2006, available at http://vip.bokee.com/article.php?id=197040 (last visited 11 May 2007), in Martin K. Dimitrov, "Understanding Communist Collapse and Resilience," Why Communism Did Not Collapse: Understanding Authoritarian Regime Resilience in Asia and Europe, (Cambridge University Press, 2013), 238.

${ }^{31}$ Edmund Malesky, Regina Abrami and Yu Zheng, Institutions and Inequality in Single-Party 
Speaking of the executives first, China has endowed its supreme leader with a "trinity" of positions that unify command of the Party-State: President of the State, General Secretary of the CCP, and Commander-in-Chief of the Armed Forces. That makes the office-holder, now Xi Jinping, incredibly powerful. Meanwhile, in Vietnam, the posts are separate: the Prime Minister is Nguyễn Tấn Dũng, the General Secretary is Nguyễn Phú Trọng, and the Commander-in-Chief is also the President of Vietnam, currently Trương Tấn Sang. Political observers indicate that those three individuals represent different political factions within the VCP, perhaps as the result of a grand bargain. Prime Minister Dung is portrayed as a pro-Western reformer, President Sang a pro-reform moderate, and Party Secretary Trong a conservative, pro-Chinese hand. ${ }^{32}$

Power is also more diffuse throughout the legislative organs of the Vietnamese Party-state. For example, the ultimate political power in China rests in the CCP Politburo (25) and especially its Standing Committee (currently 7 members, down from 9 in 2013), with the Central Committee (205 full members and 171 alternate members) playing only a ceremonial role. ${ }^{33}$ Adding the 2987 representatives of the National People's Congress, that is a total of roughly 3395 representatives for 1.3 billion people, each representing 435,000 souls. Meanwhile, in Vietnam, the 150-strong VCP Central Committee has been grappling for power with the smaller Standing Committee (15), while the state's National Assembly contains 498 members. That amounts to roughly 660 people presiding over 90 million souls, or one representative for every 136,000 .

The VCP's broader Central Committee has been a relevant decision-maker since

\footnotetext{
Regimes: A Comparative Analysis of Vietnam and China, 43:4 Comparative Politics 409 (July 2011). ${ }^{32} \mathrm{http}: / /$ thediplomat.com/2015/07/vietnam-after-2016-who-will-lead/

$3318^{\text {th }}$ Communist Party of China Central Committee [Zhongguo gongchandang di shiba jie zhongyang weiyuanhui] available at http://news.xinhuanet.com/ziliao/2012-11/15/c_123854387.htm (last visited 17 Oct. 2015).
} 
the demise of General Secretary Le Duan in 1986, with some claiming that it is superior to a Standing Committee that has been reduced to "a glorified secretariat." 34 Indeed, that Central Committee has grabbed attention for an ability, though rarely manifested, to reject recommendations on significant political decisions from the Politburo. ${ }^{35}$ The Central Committee's apparent power was demonstrated in October 2012, when it reversed a Politburo decision initiated by General Secretary Trong to discipline Prime Minister Nguyen Tan Dung for economic mismanagement and nepotism. ${ }^{36}$ It next rejected Trong's recommendation of two persons to the Politburo in May 2013, opting for its own favored candidates. ${ }^{37}$ Another unprecedented vote of no confidence for 20 top party officials was overcome by Prime Minister Dung's faction in the Central Committee in January $2015 .{ }^{38}$ Meanwhile, across the divide, senior members of the National Assembly have boldly criticized the Prime Minister, ${ }^{39}$ while another proposed that Vietnam should adopt a bicameral legislature with the National Assembly serving as the lower house and the VCP's Central Committee as the senate. ${ }^{40}$ While corruption, patronage and factional politics are common issue facing both the CCP and VCP, power is much more centralized in the CCP where political competition is much less visible.

While what we know of these events clearly suggests significant internal power struggles, this broader coalition enables wider political participation and more fierce

\footnotetext{
34 Malesky, Abrami and Zheng, Institutions and Inequality, supra note 31, at 13.

35 Id. (Malesky, Abrami and Zheng)

36 http://thediplomat.com/2015/07/vietnam-after-2016-who-will-lead/

${ }^{37}$ Le Hong Hiep, "Power Shifts in Vietnam's Political System," East Asia Forum, 5 Mar. 2015, available at http://www.eastasiaforum.org/2015/03/05/power-shifts-in-vietnams-political-system/ (last visited 15 Oct. 2015).

${ }^{38}$ Votes in June 2013, November 2014, and January 2015, respectively, See http://www.bloomberg.com/news/articles/2014-11-15/vietnam-confidence-vote-reveals-jockeying-amo ng-political-elite

${ }^{39} \mathrm{http}: / / w w w . b b c . c o m / n e w s /$ world-asia-20322830

40 Le Hong Hiep, "Power Shifts in Vietnam's Political System," East Asia Forum, 5 Mar. 2015, available at http://www.eastasiaforum.org/2015/03/05/power-shifts-in-vietnams-political-system/ (last visited 15 Oct. 2015).
} 
competition for power in Vietnam than in China. There is, for example, no formal, competitive procedure for joining Politburo or the Standing Committee in China, and the rejection rate of nominees to the ceremonial Central Committee is only between 4 to 8 percent. In Vietnam, on the contrary, the gap between nominated candidates and elected members in the Central Committee is $23 \%$ for full members and $54 \%$ for alternate members. ${ }^{41}$ A larger circle of decision-makers composed of more representative competing factions could produce different political consequences, one of which being that the political process in Vietnam appears relatively more open, more representative of diverse interests, and potentially more accountable to the larger society.

Vietnam's broader political participation and more fierce political competition make the VCP more accountable, both horizontally and vertically, than the $\mathrm{CCP}{ }^{42}$ Political pluralism at the elite level has had a cascade impact in making the atmosphere surrounding legal processes more transparent. There has been more competition between the Party and the state, and disagreements among different state organizations can be openly manifested. In a famous case, the Vietnamese police promulgated a "one person, one motorcycle" policy, and following that policy, the Hanoi government suspended registration of motorcycles in some of the city's districts. ${ }^{43}$ The restriction inspired deep hostility and resistance among Vietnam's motorcycle users, leading to fierce social mobilization and public debate over constitutional property rights. The Hanoi government and the police held their ground, but the Ministry of Justice and National Assembly eventually threatened legal

\footnotetext{
${ }^{41}$ Malesky, Abrami and Zheng, Institutions and Inequality, supra note 31, at 17.

${ }^{42}$ Martin K. Dimitrov, "Understanding Communist Collapse and Resilience," Why Communism Did Not Collapse: Understanding Authoritarian Regime Resilience in Asia and Europe, (Cambridge University Press, 2013) 32.

${ }^{43}$ Bui Ngoc Son "Constitutional Developments in Vietnam in the First Decade of the $21^{\text {st }}$ Century," in Albert H.Y. Chen, Constitutionalism in Asia in the Early Twenty-First Century (Cambridge University Press, 2014), 206-07.
} 
challenges, forcing them to back off. ${ }^{44}$

In contrast, $\mathrm{CCP}$ elites are more monopolistic and retain more extensive and institutionalized control over state apparatuses, even overriding state organs in making and implementing decisions. The CCP is deeply embedded in government departments and exercises routine political control of state institutions and public authorities. $^{45}$ It relies on informal institutions under the control of the Party known as "small leading groups" which cut across any perceived boundary between Party and State. ${ }^{46}$ These CCP cells play a key role in decision-making within Chinese state organs and are increasingly asserting political control in private sector law firms, accounting firms, and NGOs. ${ }^{47}$

There also appears to be a stronger political will for and deeper commitment to structural reform in Vietnam. After a fierce debate, the Vietnamese chose to ratify a new constitution in 2013, rather than amend the old. During the debates, the National Assembly took a strong position in supporting a proposed Constitutional Council. ${ }^{48}$ Prior to the abrupt final decision not to adopt it, elements of Vietnamese society undertook a rich discussion of constitutional review that advanced the concept of building such an independent constitutional adjudication forum quite far. ${ }^{49}$ To date,

\footnotetext{
44 Interestingly, when the Guangdong police banned the use of motorcycles in the city, the police only faced a legal challenge by the motorcycle manufacturers. Jim Yardley, N.Y. Times Asia Journal, "In City Ban, A Sign of Wealth and Its Discontents," 15 Jan. 2007, available at http://www.nytimes.com/2007/01/15/world/asia/15china.html?_r=0 (last visited 17 Oct. 2015).

${ }^{45}$ Id. at Regina Abrami, Edmund Malesky and Yu Zheng, "Vietnam through Chinese Eyes: Divergent Accountability in Single-Party Regimes," p. 259-61.

${ }^{46} \mathrm{Id}$.

47 Id. See Sarah Biddulph The Stability Imperative Human Rights and Law in China, (UBC Press, 2015).

48 Le Nhung, "Will Vietnam Have Constitutional Council or Constitutional Court?," VietnamNetBridge, 21 Feb. 2013, available at http://english.vietnamnet.vn/fms/government/66904/vietnam-will-have-constitutional-council-or-consti tutional-court-.html (last visited 17 Oct 2015); Vietnam News, "NA Deputies Discuss Constitutional Council," 2013, available at http://vietnamnews.vn/in-bai/240346/na-deputies-discuss-constitutional-council.htm (last visited 17 Oct. 2015).

49 Id. "NA deputies' two-day discussion on draft amendments to the Constitution, which was
} 
the only known comparable example in China was for a retired Chief Justice to call for the creation of a similar institution at a quasi-official function, ${ }^{50}$ while the CCP largely associates such suggestions as heresies associated with color revolutions to be perpetrated by Western powers and their domestic agents. ${ }^{51}$ Indeed, whereas Vietnam appears to be liberalizing its perspective on consultation, input and debate since 2013, China has opted to go in the opposite direction, rendering the terms "constitutionalism," "civil society," and "judicial independence" (among others) taboo in academic discourse. ${ }^{52}$

Intriguingly, the Vietnamese are currently debating procedural rules both for holding public demonstrations and voting in referendums. The former is meant to actualize a limited and issue-specific freedom to assemble granted in Article 25, and has been boosted by recent nationalist sentiment against China. ${ }^{53}$ Of more structural interest, Article 29 grants the right to vote in a referendum to any person over 18 years

broadcast live on national radio and TV, drew great attention from voters around the country." For a discussion of the drafting process, see Bui Hai Thiem, "Pluralism Unleashed: The Politics of Reforming the Vietnamese Constitution," Journal of Vietnamese Studies, Vol. 9, Issue 4, pp. 19-22 (2014); and Pip Nicholson, Asian Journal of Comparative Law, Vol. 11, pp. 199-207 (2016).

50 Beijing Youth Newspaper, "Former Chief Justice of the Supreme People's Court Suggesting the Establishment of a Constitutional Court," available at http://www.chinalawinfo.com/news/NewsFullText.aspx? NewsId=70635\&NewsType=0 (last visited 19 Oct. 2015).

51 According to Hand, one of the main reasons not to introduce a constitutional committee within China's NPC to police the legislative order is the concern that creating such a constitutional committee will further generate citizen activism and offer a forum for politically sensitive questions. Hand, "An Assessment of Socialist Constitutional Supervision Models and Prospects for a Constitutional Supervision Committee in China: The Constitution as Commander?" in China's Socialist Rule of Law Reforms Under Xi Jinping, John Garrick and Yan Chang Bennett (eds.), (forthcoming, Routledge, 2016); See also Rogier Creemers, China's Constitutionalism Debate: Content, Context and Implications, 74 The China Journal, July 2015, pp. 91-109.

52 The Party issued a document which lists 7 topics which are off limit in public discussion, commonly referred to 7 prohibitions. It is telling that the Party classified the said document as state secret and sentenced Ms Gao Yu, a 70 year veteran journalist, to 7 years' imprisonment for leaking the document. See 22 April 2013, "Report Concerning the Present Situation in the Ideological Area"; Stanley Lubman, "Document No. 9: The Party Attacks Western Democratic Ideals," Wall Street Journal China Real Time Report, 27 Aug. 2013.

53 "Dang Ngoc Tung, president of the Vietnam General Confederation of Labor, and Tran Thi Quoc Khanh, a Hanoi deputy, also said they agreed with the suggestion that the Bill on Demonstrations be effective in 2016. 'In the context that China has committed wrongdoings that violated our country's sovereignty, many people want to express their patriotism and aspirations,' Tung said." Tuoi Tre News, 28 May 2015, "Vietnam lawmakers want Law on Demonstrations to be Passed Next Year," available at http://tuoitrenews.vn/society/28354/lawmakers-want-law-on-demonstrations-to-be-passed-next-year (last visited 7 Nov 2015). 
old in any referendum declared by the National Assembly (Article 70) and organized by the Standing Committee of the National Assembly (Article 74). Although there have not been any as of this date, the matter was warmly debated at a series of three conferences in 2015, including by legal academics and members of the Ho Chi Minh City bar association at a conference held at the Ho Chi Minh City University School of Law in June $2015 .^{54}$ Though unlikely to be implemented in the near future, such a move would be a remarkable leap in socialist constitutional development. In terms of Vietnamese constitutional text, it would help promote the People's mastery (Art. 2) and assist the VCP in developing "close ties with the People," "submitting to People's supervision," and assure that the VCP is "accountable to the People in its decisions" (Art. 4[2]).

In any event, it is probable that the Central Committee will continue to aggregate power after the upcoming $12^{\text {th }}$ National Congress in 2016 if Dung ascends to Party Chairman and the Central Committee can defend and maintain its ability to conduct confidence votes on top party officials. In concert, these developments indicate that the VCP appears to be relatively more open-minded and pluralistic in its exercise of political power within its authoritarian context, rendering its current state of reform progress more "politically consequential" than that of China. ${ }^{55}$

\section{Commitment to Socialist Rule of Law}

Both China and Vietnam advocate the development of a so-called socialist rule of

${ }^{54}$ Domestic commentators were quite clear in arguing that a referendum must be binding, because to make it advisory would change the definition of the word referendum to equate it with "consultation." The majority of their efforts in drafting a recommendation paper to the government focused on narrowing substantive matters capable of submission to referendum. Foreign speakers from Sweden, Canada, and the United States presented alternative views, and the chairman announced that 20 sample referendum laws from other jurisdictions had been officially translated for sending to the government.

55 Bui Ngoc Son, "The Discourse of Constitutional Review in Vietnam," 9:2 Journal of Comparative Law (2014), 175-205. 
law. Since shedding their totalitarian approaches decades ago, both Parties have been more reluctant to exercise naked political power. They instead resort to legal institutions to manage and coordinate massive socioeconomic transitions and maintain credibility. Legal reform in authoritarian states is a contradictory process, however, because it can generate tremendous societal demand for individual rights and government accountability. Thus, while the Party-states employ law to achieve certain objectives, they attempt to limit legal reform so as to prevent any political spillover. Vietnam's experiment has been proceeding in a more internationalist fashion, however, as it has been more welcoming of foreign normative influences, especially in the field of human rights.

What comprises socialist rule of law is the subject of much debate. Chinese and Vietnamese "socialism" appears very different from European "socialism." classifies the Chinese and Vietnamese orders as "socialist" perhaps more than anything else is their self-identification; what separates them most obviously from European models is their Leninist political structure. Leninism includes a doctrine positing that vanguard communist parties do not have an interest independent of that of the "People," as they completely discern and represent their common interest. As Nathan put it, the Party asserts that it and the People "have a fundamental harmony of interests" which makes democracy and accountability redundant and potentially harmful. ${ }^{57}$ A fundamental change occurred upon the collapse of this doctrine in China and Vietnam during the period of economic reform, which was accompanied by the surfacing of diverse, pluralistic social interests. Having recognized the perennial existence of social conflict, the Parties must design rules and institutions to manage and preserve harmony. Both the CCP and the VCP have managed developments in

\footnotetext{
${ }^{56}$ Dowdle

57 Andrew Nathan, Chinese Democracy (University of California Press), 228.
} 
response to complex socioeconomic circumstances and, as a result, there have been visible expansions or contractions of constitutional "space."

The main thread of constitutional change has been an emphasis on the rule of law and individual rights in promoting social and economic development. In China, significant constitutional amendments include the recognition of the privately-owned economy in 1988, the promotion of rule of law and construction of a socialist state of rule of law in 1999, and the duty of state to respect human rights in $2004 .^{58}$ The CCP Central Committee's Fourth Plenum in 2014 recommitted China to further development of a socialist rule of law system. ${ }^{59}$ The new Vietnamese Constitution of 2013 contains significantly more phrasing of substantive rights than before. Meanwhile, legal reform in both countries has included an explosion of legislation, the professionalization and institutionalization of legal institutions, a growing numbers of legal professionals to channel disputes from society to state institutions and, above all, an effort to inculcate a new popular legal culture. ${ }^{60}$

Rule of law, in order to be credible in the eyes of the public, must be able to regularize, normalize, and discipline the exercise of power. The CCP and VCP have thus established self-limiting and self-correcting mechanisms, such as the strengthening of intra-Party anti-corruption enforcement, ${ }^{61}$ although the Chinese efforts have been much stronger in this regard. The Chinese central inspection system

\footnotetext{
581982 Chinese Constitution, amendments of 1988 (first), 1999 (third), 2004 (fourth).

59 Communique of the 4th Plenary Session of the 18th Central Committee of CCP (23 Oct. 2014), available at http://www.china.org.cn/china/fourth_plenary_session/2014-12/02/content_34208801.htm (last visited 17 Oct. 2015).

60 See Fu Hualing, “Access to Justice in China: Potentials, Limits and Alternatives,” in Gillespie \& Chen, Legal Reforms in China and Vietnam: A Comparison of Asian Communist Regimes (New York: Routledge, 2010) pp. 163-187; Brian J.M. Quinn, "Vietnam’s Continuing Legal Reform: Gaining Control Over the Courts," 4(2) Asian Pacific L. \& Policy J., 431, 449-57 (Spring 2003).

61 Earlier, the fourth plenum of the 11th Communist Party Central Committee issued a resolution on "urgent issues in Party building." These measures aimed to create a sort of checks and balances mechanism within the CPV with the goal of resolving the challenges the party faces. (http://thediplomat.com/2015/02/2015-challenges-for-the-communist-party-of-vietnam/)
} 
was strengthened in 1990 and codified in the CCP Constitution at the 17th Party Congress in 2007 , with a series of new measures being unveiled since, especially after a renewed anti-corruption drive began with the ascendancy of Xi Jinping in $2012 .{ }^{62}$ Meanwhile, the Vietnamese issued a resolution on "urgent issues in Party building" at its fourth plenum of the 11th Party Conference in 2011, but elaboration has been relatively lacking, and a comprehensive "Law on the Party" proposal put forward by the Fatherland Front was rejected in $2013 .^{63}$ The new 2013 Constitution did add two important stipulations to the old Article 4, however, declaring the accountability of the VCP to the people in its decision-making capacity as well as the subjugation of VCP members to the Constitution and the law. ${ }^{64}$ Incentives for such self-regulation exist despite the lack of an institutionalized system of checks-and-balances. Indeed, both countries appear to have reached a stage where their Party-states must figure out how to commit themselves to the rule of law systems they themselves created. This is not because of a serious and credible commitment to the rule of law on the part of the Party-state, but rather internal corruption scandals and a demand emanating from civil society to hold the Party-state accountable to its own rhetoric.

The development of socialist rule of law in China and Vietnam differs from the liberal conception of rule of law in at least three other major respects: the prevalence of a statist stance in imposing legal norms and creating institutions, selective rights extension, and thin (versus thick) legal protections. In developing socialist rule of law,

\footnotetext{
62 Given that the commanding heights of Chinese elite politics are now more monolithic than in Vietnam where power is more diffuse among factions, this perhaps indicates that such "anti-corruption" measures can be hijacked and conflated with more political purposes.

${ }^{63}$ Hoàng Thái, a former standing member of the VFF Central Committee, made a very sharp comment in 2013: "There are laws all on the State, the NA, the VFF, but no law on the party. There must be a law on the party to ensure openness and transparency as well as to avoid arbitrariness," "Góp ý sửa Hiến pháp: Phải có luật về sự lãnh đạo của Đảng" [Contribution to the Constitutional Amendments: There Must be a Law on the Party's Leadership], VnEconomy, February 2013, cited in Bui Hai Thiem, "Pluralism Unleashed: The Politics of Reforming the Vietnamese Constitution," Journal of Vietnamese Studies, Vol. 9, Issue 4, p. 16 (2014).

64 Bui Hai Thiem, "Pluralism Unleashed: The Politics of Reforming the Vietnamese Constitution," Journal of Vietnamese Studies, Vol. 9, Issue 4, pps. 13-19 (2014).
} 
China and Vietnam demonstrate unique characteristics strongly associated with their national cultures and ideological debates. ${ }^{65}$ Yet, by placing both countries in the larger historical and comparative context, Peerenboom argues that they have been following a fairly typical East Asian Model (EAM) of development despite their professed allegiance to communism. ${ }^{66}$ Thus, there are a number of similarities between the two countries in key areas of law reform and legal development.

First, owing to their statist stances in imposing legal norms and creating institutions, both states prioritize the "supply side" of the rule of law and rights protection while managing a gradual shift to the demand side. ${ }^{67}$ The supply side includes establishing both constitutional and legal rules, and institutions (i.e., courts) to apply them. ${ }^{68}$ The demand side includes rights-awareness on the part of the citizens, as well as tolerance of lawyers and social organizations in channeling disputes into legal institutions that facilitate rights protection. ${ }^{69}$ It is to be expected at the beginning of a rule of law building process that rule-making, as a top-down process, has priority. After all, rules must be in existence before they can be enforced. Once promulgated, the issue becomes whether those rules actually are enforced or remain mere "window-dressing."70 Therefore, the second stage of reform regards

\footnotetext{
65 Gillespie and Chen; and Sidel.

66 That model begins with a state-led economic reform, followed by the development of commercial rule of law to facilitate a market economy. In the initial stage, the state promotes civil law rights (i.e., freedom of contract) and socioeconomic rights (i.e., consumer and labor rights), while limiting collective rights and political rights. As the economy grows, the state invests more in institutions, improves education and professional training (including for legal professionals), and diverts resources to human development. From that stage onward - the argument goes - the state is on the defensive and starts to guard its power and privilege, refusing to make further concessions unless absolutely necessary, although there is persistent demand for rule of law, accountability, and an expansion of rights. Randall Peerenboom, "Rule of Law, Democracy and the Sequencing Debate, Lessons from China and Vietnam," Chapter 2 of Gillespie \& Chen, 2010.

${ }^{67}$ Fu Hualing, Challenging Authoritarianism through Law: Potentials and Limits, 6(1) Nat'1 Taiwan University L. Rev. 331, 345-46 (2011).

${ }^{68} I d$.

69 Id.

70 Tom Ginsburg and Alberto Simpser describe "window dressing" in Constitutions in Authoritarian Regimes (London: Cambridge University Press, 2012), pp. 7-8.
} 
institutional capacity-building.

Both China and Vietnam have an adequate supply of baseline rules and institutions, but there seems to be insufficient channeling into dispute resolution fora. ${ }^{71}$ This weak channeling function appears to be a critical bottleneck in both efforts toward law reform, as it has been in the case other developing countries. ${ }^{72}$ As Epp argues, what distinguishes a weak legal system from a strong legal system is not rules or institutions, but what he refers to as the "support structure," including the legal profession, legal aid, access to justice, NGOs, and other intermediaries that perform a channeling function. ${ }^{73}$ Both China and Vietnam are developing legal aid services, improving access to courts and other dispute resolution mechanisms, and otherwise strengthening the demand side of the rule of law but, at the same time, deeply worry about the political risk of increasing legal consciousness among the citizenry and at the same time placing the supply side of the legal system, the judiciary in particular, under the Party's firm control. ${ }^{74}$

Second, both Party-states are selective in terms of which rights they liberalize. Within limited political contexts, both demonstrate that it is possible for authoritarian states to respect some degree of personal freedom, individual rights, and rule of law. Indeed, the CCP has proven itself adaptable and resilient in the eyes of the general

${ }^{71}$ Scholars have observed that the problem is not with having laws to follow, but rather people disregarding the law. See James D. Seymore, "Human Rights and the Law in the PRC" in Victor C. Falkenheim (ed.) Chinese Politics from Mao to Deng (N.Y.: Paragon House, 1989), pp. 271-299, 272.

${ }^{72} \mathrm{Fu}$ Hualing, "Access to Justice and Constitutionalism in China," in Balme and Dowdle.

${ }^{73}$ Charles Epp, The Rights Revolution: Lawyers, Activists and Supreme Courts in Comparative Perspective (Chicago: Chicago University Press, 1998), 6-21.

74 Mark Sidel, Law and Society in Vietnam: The Transition from Socialism in Comparative Perspective (Cambridge: Cambridge University Press, 2008), 60; see also Nicholson and Pham in this volume and Fu Hualing, Fu Hualing, Building Judicial Integrity in China, Hastings International and Comparative Law Review, 2016, vol. 39 no. 1, pp. 167-181 (2016) 
public because of the promulgation and enforcement of a bundle of legal rights. ${ }^{75}$ Meanwhile, the ratification of a new, more approachable 2013 constitution signals that Vietnam has the will and capacity to pursue more progressive changes. But, like other transitional states, both China and Vietnam prioritize rule of law and the protection of rights in selective policy areas depending on perceived necessity and feasibility. There is greater rule of law in matters of commerce than in media, religion, criminal law and other politically sensitive areas. ${ }^{76}$ It is therefore not surprising that Vietnamese constitutionalism was most forcefully asserted in the aforementioned motorcycle case, ${ }^{77}$ while the Chinese Supreme People's Court chose to test the feasibility of constitutional review in a case regarding educational rights. ${ }^{78}$

On the contrary, there are areas, such as anti-corruption and media governance, where formal law remains largely silent. ${ }^{79} \mathrm{~A}$ dualism exists wherein professional justice serves the vast majority of ordinary cases while politicized justice caters to a range of exceptional cases. ${ }^{80}$ That dualism causes a dilemma for the judiciary when facing cases of different political natures. For example, Chinese judges are totally supervised by political instructions in exceptional cases, but perhaps too independent

\footnotetext{
75 See David Shambaugh, China's Communist Party: Atrophy and Adaptation (Washington DC, Woodrow Wilson Center Press, 2008).

76 During the 1990s, Vietnamese lawmakers borrowed or drew inspiration from laws multilateral international institutions such as the World Bank, including in drafting the 1993 Law on Business Bankruptcy, 1995 Civil Code, 1997 Commercial Law, and the 1999 Enterprise Law. Chen \& Gillespie, 8.

77 Bui Ngoc Son "Constitutional Developments in Vietnam in the First Decade of the $21{ }^{\text {st }}$ Century," in Albert H.Y. Chen, Constitutionalism in Asia in the Early Twenty-First Century (Cambridge University Press, 2014), 206-07.

78 Robert K. Morris, “China’s Marbury: Qi Yuling v. Chen Xiaoqi - The Once and Future Trial of Both Education and Constitutionalization,” 2 Tsinghua China Law Review 273-316 (2012).

${ }^{79} \mathrm{Fu}$ Hualing, "Wielding the Sword: President Xi's New Anti-corruption Campaign," Chapter 5 in Susan Rose-Ackerman and Paul Lagunes, Greed, Corruption, and the Modern State: Essays in Political Economy (Edward Elgar Publisher, 2015) 134-57.

${ }^{80}$ Such as the high-profile trials of Bo Xilai, Zhou Yongkang and others in the current Xi Jinping anti-corruption campaign in China. Meanwhile, Vietnamese Prime Minister Nguyen Tan Dung also declared anti-corruption a priority, establishing a new anti-corruption agency to be headed by the Deputy Prime Minister. A major corruption scandal within the Ministry of Transport in 2006 led to high-level resignations and arrests, including the Vice Minister of Transport.
} 
in other ordinary cases. ${ }^{81}$ Both China and Vietnam have been regularizing and professionalizing their court procedures, ${ }^{82}$ but such professionalism encounters insurmountable difficulties inherent to the political system. ${ }^{83}$ Dissident trials, which have become a regular practice in both countries, illustrate the pain of authoritarian states struggling with rule of law.

Third, in both countries, the present state of reform promotes a thin/formal version of the rule of law without dealing with the hard questions posed by a thick/substantive rule of law. The thin version focuses on the internal qualities of law, such as the requirements that law must be public and accessible, generally applicable, and largely consistent. ${ }^{84}$ It also focuses on the institutional dimension of enforcement and requires valid rules for law-making, fair application, effective enforcement and general acceptance of rules. ${ }^{85}$ Critics who challenge the existence of a "thin" rule of law point out that it does not provide a normative foundation, and is not supported by the sort of rights-based system commonly observed in a liberal democracy. ${ }^{86}$ Indeed, legal reform in this context is largely illiberal in the sense that the legal system under construction is not rights-based. Instead, reform efforts have been concentrated on developing a system that better ensures certainty, clarity and, to some extent, procedural fairness. Such law reform is thus at improving government effectiveness

${ }^{81}$ Fu Hualing "Putting China's Judiciary into Perspective: Is it Independent, Competent and fair?" Erik Jensen \& Tom Heller, (eds.) Beyond Common Knowledge: Empirical Approaches to the Rule of Law (Stanford University Press: 2003), pp. 193-219

${ }^{82}$ See Gillespie and Chen, Legal Reforms in China and Vietnam: A Comparison of Asian Communist Regimes (New York: Routledge, 2010).

83 "Vietnam's 2005 Anti-Corruption Law requires government officials to declare their assets and sets strict penalties for those caught engaging in corrupt practices. Implementation and enforcement, however, continues to remain problematic. Vietnam also signed the United Nation Convention on Anti-Corruption in July 2009." U.S. Dept. of State, "2013 Investment Climate Statement - Vietnam," Feb. 2013, available at http://www.state.gov/e/eb/rls/othr/ics/2013/204760.htm (last visited 17 Oct. 2015).

${ }^{84}$ Peerenboom, China's Long March, pp. 3-7.

85 Id.

${ }^{86}$ Brian Tamanaha, A Concise Guide to the Rule of Law, St. Johns University School of Law. Legal Studies Research Paper Series, Paper \#07-0082 (September 2007), pp. 16-20. 
and enhancing state capacity.

Despite these underlying similarities, China and Vietnam differ in interesting ways on their official commitment to and societal demand for the rule of law. Rhetoric praising rule of law and the supremacy of the constitution is more often relied upon in China by emerging political leaders when facing challenges from more established authorities. Once those leaders consolidate their power, however, rule of law and constitutionalism typically become less relevant. ${ }^{87}$ Vietnam, because of broader participation and more fierce competition among different factions, may depend more upon rule of law as a fundamental code of the political game. This - and the apparent rise of a pro-reform faction - may help to explain why the Vietnamese Constitution evinces deeper normative commitments than its Chinese counterpart.

Though abuses persist, Vietnamese leaders have been more receptive to incorporating international best practices, especially in the field of human rights. Human rights received constitutional recognition in the Vietnamese Constitution of 1992, twelve years before it was added via amendment to the Chinese Constitution in 2004. ${ }^{88}$ Prior to that, Vietnam ratified the International Covenant on Civil and Political Rights (ICCPR) in $1982 .{ }^{89}$ Article 70(14) of the 2013 Constitution mentions a general commitment to international human rights treaties and fundamental citizens' rights, ${ }^{90}$ while Article 31 showcases a commitment to human rights norms vis-à-vis the practice of criminal justice at a level of detail matched by few national

\footnotetext{
${ }^{87}$ Fu Hualing, "Challenging Authoritarianism through Law: Potentials and Limits" 6 Nat'l Taiwan University L. Rev. 339-365 (2011).

88 Vietnamese Constitution (1992), Art. 50, read "[i]n the Socialist Republic of Vietnam, human rights in all respects, political, civic, economic, cultural and social are respected, find their expression in the rights of citizens and are provided for by the Constitution and the law."

89 United Nations Office of High Commissioner for Human Rights, Status of Ratification [ICCPR], available at http://indicators.ohchr.org/ (last visited 17 Oct. 2015).

90 Vietnamese Constitution (2013), Art. 70(14).
} 
constitutions in such detail. ${ }^{91}$ The partial entrenchment of the ICCPR has the potential to open the door for further reform. Whereas the Basic Laws of Hong Kong and Macau incorporate the ICCPR, ${ }^{92}$ it remains wishful thinking on behalf of Chinese constitutional scholars to entrench such core rights in the national Constitution. China signed the ICCPR 16 years after Vietnam and has yet to ratify it. ${ }^{93}$ This may have practical effect. Vietnam appears relatively more committed to reforming use of the death penalty. It abolished execution by firing squad in favor of legal injection more decisively than China. ${ }^{94}$ Extraordinarily, in 2007 Vietnam abstained from the UN resolution calling for a global moratorium on execution with the ultimate goal of abolishing the death penalty, effectively making Vietnam the only Asian retentionist country which did not object to the resolution. ${ }^{95}$

\section{Responsiveness to Civil Society and Public Demands}

Party-states must be responsive to popular will to ensure regime survival and political stability. While the promotion of rule of law generates further demand for rights in both countries, their limited legal systems are hard pressed to meet the challenges brought by massive socioeconomic transition due to a lack of capacity and credibility. The Party-states must directly face those challenges and may at times

\footnotetext{
91 Vietnamese Constitution (2013), Art. 31(1-5), including: presumption of innocence (1), timely access to trial (2), prohibition of double-jeopardy (3), access to attorneys (4), and right to punitive damages for unlawful prosecution (5).

92 Article 39 of the Basic Law of the Hong Kong Special Administrative Region; Article 40 of the Basic Law of the Macau Special Administrative Region.

93 United Nations Office of High Commissioner for Human Rights, Status of Ratification [ICCPR], available at http://indicators.ohchr.org/ (last visited 17 Oct. 2015).

94 An Dien, "Vietnam Switched from Firing Squad to Lethal Injection in 2011," Thanh Nien News, available at http://www.thanhniennews.com/politics/is-vietnam-ready-to-abolish-death-penalty-37916.html (last visited 17 Oct. 2015).

95 David T. Johnson and Michelle Miao, "Chinese Capital Punishment in Comparative Perspective," in Bin Liang and Hong Lu (eds.) The Death Penalty In China: Policy, Practice, and Reform (New York: Columbia University Press, 2015).
} 
choose to supplement or subvert the legal systems they have created. Chinese and Vietnamese constitutional practice therefore necessitates a responsive and proactive state, based on political expedience rather established legal rules, in managing and coordinating popular demand for rights and interests. The Vietnamese Party-state appears to be situated in a "better" (i.e., less defensive) posture than its Chinese counterpart, as the Vietnamese order is more tolerant of input from a more autonomous civil society. Indeed, some Vietnamese politicians have called for an event more resilient civil society. ${ }^{96}$ Nonetheless, both systems often fail to meet such demands, resulting in extrajudicial action by the people themselves.

Constitutionally, the people are the master of the state in China, and are the protector of the Constitution in Vietnam. ${ }^{97}$ Thus, a feasible theory of socialist constitutionalism demands that law reflect and reinforce popular will in both countries. Both the $\mathrm{CCP}$ and $\mathrm{VCP}$ have proven responsive (sometimes over-responsive) to popular demand, yet the Vietnamese Party-state is presently far more respectful of voices from civil society than its Chinese counterpart. That Vietnam would possess a more structured and vibrant public sphere is consistent with Vietnam's higher degree of political pluralism and deeper commitment to international norms. It boasts a healthier interface between the Party-state and civil society, as evinced by: (1) a more activist

\footnotetext{
96 <http://vneconomy.vn/thoi-su/da-den-luc-thua-nhan-xa-hoi-dan-su-20140429110559789.htm> [This article cites the statement of Mr Truong Dinh Tuyen--former Minister of Industry and Trade--at the 2014 Spring Economic Forum--a regular event of the Vietnamese National Assembly--that Vietnam should accept civil society to address shortcomings of a market economy and the bureaucratic government.] <http://www.thesaigontimes.vn/115717/Dai-bieu-Quoc-hoi-Dung-ao-tuong-ve-16-chu-vang.html> [This article reports that Mr Ha Sy Dong--a delegate of the National Assembly--called in a plenary session that civil society be promoted. Interestingly, this call was made in the context of the China-Vietnam conflict in the Southeast China Sea.]

97 Article 2(2) of the Vietnamese Constitution (2013) reads: "The people are the masters of the Socialist Republic of Vietnam; all state powers belong to the people whose foundation is the alliance between the working class, the peasantry and the intelligentsia." Chinese Constitution (1982) Preamble, para. 2, reads "the Chinese people took state power into their own hands and became masters of the country," the phrase is repeated in Article 42.
} 
labor sector, (2) a more vibrant religious community, and (3) a more independent lawyers' bar association. On the contrary, the Chinese Party-state, in comparison, has been more decisive and harsh in cracking down on civil organizations and silencing dissenting voices.

\section{(i) Labor}

Labor unions in both countries are dominated by their respective communist parties and serve a "transmission belt" of intelligence. ${ }^{98}$ Faithful to their ideological roots, both constitutions devote special attention to protect the rights of the toiling people. For example, Chinese workers enjoy constitutional rights to work and rest. ${ }^{99}$ In that sense, the Chinese Constitution is nominal, but its constitutional provisions are not fully implemented due to the lack of resources and issues of implementation. The Vietnamese Constitution, meanwhile, grants constitutional status to a Trade Union intended to protect workers' rights. ${ }^{100}$ In practice, Vietnam's labor relations regime more closely tracks ILO standards. For example, Vietnamese labor law includes a National Wage Council modeled on a South Korean example with technical assistance from ILO. Composed of members from the government, unions and business associations, that tripartite body has been effective in advising decision-makers on minimum wages. ${ }^{101}$ Vietnam is thus ahead of China in legalizing industrial action.

98 Erwin Schweisshelm, "Trade Unions in Transition - Changing Industrial Relations in Vietnam," Friedrich Ebert Stiftung Vietnam Office Briefing Paper, September 2014, available at https://www.fes.de/gewerkschaften/common/pdf/2014_09Vietnamese_TU_in_Transition.pdf (last visited 17 October 2015), 1.

99 Chinese Constitution (1982), Arts. 42 and 43.

100 Vietnam Constitution (2013), Art. 10, reads: "The Trade Union is the socio-political organisation of the working class and labourers, established on a voluntary basis that represents the workers, looks after and protects the legitimate and legal rights and interests of the workers; participates in state administration and socio-economic management; participates in the control, inspection, and supervision of the activity of State bodies, organisations, units and enterprises with respects to the matters concerning the rights and duties of the workers; propagandises, mobilises learning, development of abilities and professional skills, conformity of law, and construction and defence of the Fatherland among the workers."

101 Vietnamese Prime Minister Nguyen Tan Dung approved Decree 49/2013/ND-CP, which commissioned the establishment of a National Wage Council to oversee national wage levels 
These developments may come in handy, as both countries experience interest-based industrial action and mass strikes that are likely to increase in size and frequency. ${ }^{102}$

The Vietnamese labor law has long authorized strikes under certain circumstances, although those conditions are hard to fulfill, ${ }^{103}$ while unions and professional organizations, in spite of their dependence on the VCP, can be relatively more spontaneous and representative than their Chinese counterparts in representing workers' interests against both the state and employers. ${ }^{104}$ For example, a significant difference between the two countries is that an enterprise union chair is paid for by unions at the next higher level in Vietnam, while their Chinese counterpart is paid for by the very enterprise the union chair serves. ${ }^{105}$ This openness reflects the historical fact that Vietnamese unions are more politically powerful in dealing with employers and structurally more autonomous of the VCP than their Chinese counterpart, the ACFTU. ${ }^{106}$

The relative strength of Vietnamese workers is also reflected in the fact that, despite the large number of illegal wildcat strikes in Vietnam, few organizers have

throughout the country. Vietnam Briefing, "National Wage Council Established in Vietnam, Minimum Wage Rises," 16 Jul. 2013, available at

http://www.vietnam-briefing.com/news/national-wage-council-established-in-vietnam-minimum-wagerises.html/\#sthash.n13yVLtv.dpuf (last visited 17 Oct. 2015).

${ }_{102}$ China Labour Bulletin, "Worker Activism is Now the New Normal as Strikes and Protests Erupt Across China," 7 Apr. 2015, available at

www.clb.org.hk/en/content/worker-activism-now-new-normal-strikes-and-protests-erupt-across-china (last visited 17 Oct. 2015); Vu Trong Khanh, "Vietnamese Workers Strike Over End of Option on Retirement Money," Wall Street Journal Asia, 1 Apr. 2015, available at

http://www.wsj.com/articles/vietnamese-workers-strike-over-end-of-option-on-retirement-money-1427 889688 (last visited 17 Oct, 2015).

${ }_{103}$ Trinh K.Y. Khanh, "The Right to Strike in Vietnam's Private Sector," 2 Asian J. of L. and Society 115-35 (2015).

${ }^{104}$ Anita Chan and Irene Norlund, Vietnamese and Chinese Labour Regimes: On the Road to Divergence, China Journal (July 1998), 192-93, available at http://www.researchgate.net/profile/Anita_Chan5/publication/260388138_Vietnamese_and_Chinese_L abour_Regimes_On_The_Road_to_Divergence/links/53fd46f00cf2364ccc08a891.pdf (last visited 17 Oct. 2015).

${ }^{105}$ Chan and Norlund, ibid, at 173.

106 A significant difference between the two countries is that an enterprise union chair is paid for by unions at the next higher level and the Chinese counterpart is paid for the enterprise the Chair serves. Id. at 185 . 
been prosecuted (although private harassment does occur). ${ }^{107}$ While there is a legal procedure for the government to petition courts for a declaration that a strike is illegal, the government has never utilized it. Instead, the dismissal of a striker often leads to renewed strikes forcing management to reinstate the dismissed workers. ${ }^{108}$ As Simon Clarke points out, official tolerance of such strikes provides the most powerful incentive for Vietnamese workers to achieve what they want through extra-legal means. ${ }^{109}$ In Khanh's view, an over-responsive state thus "has given rise to a negative precedent, making workers believe compliance with the official mechanism for collective labour dispute resolution is unnecessary."

\section{(ii) Religion}

The relative open space for religion also reflects a more resilient and rigorous demand for religious freedom in Vietnamese society. The VCP does not prohibit its members from exploring religious beliefs as the CCP does, as long as the religion is properly recognized by the state. ${ }^{111}$ It has not created a parallel Catholic Church independent of Rome, as the CCP has done; it does not force its Catholics renounce allegiance to the Vatican, as the CCP does; and it does not ordain bishops who are not endorsed by the Vatican, as the CCP does, even though it does from time to time veto

\footnotetext{
107 Ibid. See further deliberation, see Ha's chapter in the volume.

108 Simon Clarke, The Changing Character of Strikes in Vietnam, 18(3) Post-Communist Economies 346, 355 (2006).

109 Simon Clarke, The Changing Character of Strikes in Vietnam, 18(3) Post-Communist Economies 345-361 (2006).

110 Trinh K.Y. Khanh, The Right to Strike in Vietnam's Private Sector, 2 Asian J. of L. and Society, 115, 127 (2015).

111 Vietnamese Constitution (2013), Art. 24; Eleanor Albert, "Religion in China, Council on Foreign Relations Backgrounder," 10 Jun. 2015, available at http://www.cfr.org/china/religion-china/p16272 (last visited 17 Oct. 2015). For a comprehensive review of religious policy in Vietnam, see John Gillespie, Human Rights as a Larger Loyalty: The Evolution of Religious Freedom in Vietnam, Harvard Human Rights Journal, Vol. 27 (2014) pp 107-149; and Thomas J Reese and Mary Ann Gledon, How Vietnam Respects and Protects Religious Freedom has Implications beyond its Own Borders, America: The Jesuit Review (18 February 2016) https://www.americamagazine.org/issue/report-vietnam.
} 
the Vatican's recommended candidates. ${ }^{112}$ Where restriction and repression undoubtedly continue in Vietnam, the CCP has been far less permissive.

With the general improvement of relations between Vietnam and the Vatican, Vietnamese religious groups maintain stronger ties with foreign countries. While both Party-states impose strong bureaucratic control over religious organizations, Vietnamese believers are allowed practice their faith with greater confidence in the open: they can be registered as independent religious organizations with the government and thereby authorized to operate legitimately "on the ground" in parallel with directly state-controlled religious organizations. In China, no independent religious groups can exist legally outside of direct state control. They are either incorporated into the state-controlled institutions or operate as house-churches in the long shadow of the state, suffering routine harassment and crackdown. ${ }^{113}$

The VCP started to loosen its grip over religious organizations and practices in 1990, and one key development was to accept and tolerate Party members from religious communities. ${ }^{114}$ The removal of religious ban on Party members was a recognition and reflection of the importance of religion in the Vietnamese society and contributed to the creation of a more vibrant religious community that cuts across the Party-state and society boundaries. ${ }^{115}$ The participation of VCP members in religious activities legitimizes religion in general, opens a space for interaction between the

${ }^{112}$ Kevin Boyle \& Juliet Sheen (eds.), Freedom of Religion and Belief: A World Report (Routledge, 1997), 256; Andrew Batson, "China Set to Name Catholic Bishop without Consent," Wall Street Journal, 29 Nov. 2006, available at http://www.wsj.com/news/articles/SB116475889349535058 (last visited 17 Oct. 2015).

${ }_{113}$ Vietnam to date has not suppressed any cult groups as China has done against Falun Gong and Vietnamese middle class church goers have not suffered nearly as much as members of the Shouwang church in Beijing. David C. Schak, "Protestantism in China: A Dilemma for the Party-State," 2 Journal of Current Chinese Affairs, 71-106 (2011).

${ }_{114}$ Gillespie, supra note 111, p 124; and Reese and Gledon, supra. note 4.

115 The idea was mooted by some religious scholars in China but was never taken seriously by the CCP. 
state and the religious sector and, makes the police harassment less likely for the faithful. This difference in whether Party members may practice religion may help to explain why Vietnamese believers practice largely "on the ground" while their Chinese counterparts do so "underground."

(iii)

\section{The Legal Profession}

Legal professionals are active in both countries in holding the Party-state accountable to its rule of law rhetoric, despite tight government control over lawyers, firms and bar associations. ${ }^{116}$ Lawyers in both nations are endeavoring to achieve a degree of autonomy from government control but are met with a swift and harsh response, with leading lawyers selectively prosecuted for sedition, subversion or other offences. ${ }^{117}$ Yet, ad hoc evidence indicates that while Chinese rights lawyers are at least as zealous as their Vietnamese counterparts, their representative professional organizations are more timid. ${ }^{118}$

While the sheer size of the legal profession is much smaller in Vietnam than in China, ${ }^{119}$ the phenomena of "die-hard lawyers" vigorously challenging the prosecution's cases (on largely procedural matters) began in Vietnam at least as early

\footnotetext{
116 John Gillespie, "The Juridification of Cause Advocacy in Socialist Asia: Vietnam as a Case Study," 31 Wisconsin Int'l L. J. 672-701 (2014).

117 See, for example, "Vietnam Lawyer Charged with Subversion," BBC, 24 Dec. 2009, available at http://news.bbc.co.uk/2/hi/asia-pacific/8429351.stm (last visited 17 Oc. 2015); "China Dissident Lawyer Gao Zhisheng 'Destroyed by Jail,'” BBC, 14 Aug. 2014, available at http://www.bbc.com/news/world-asia-china-28793055 (last visited 17 Oct, 2015).

118 Recently, however, having witnessed the increasing level of prosecution and harassment of human rights lawyers in China, some lawyers have petitioned the NPC to have the All China Lawyers' Association abolished for failing to speak on behalf of its members. "Chinese Lawyers Call for the Abolition of Their Professional Body," ASIAN PACIFIC STAR, Vol. 417, 8 Oct. 2015, available at http://www.asiapacificstar.com/index.php/sid/237422049 (last visited 17 Oct. 2015).

${ }^{119}$ Nyuyen Hung Quang and Kerstin Steiner, "Ideology and Professionalism: the Resurgence of the Vietnamese Bar," Chapter 9 in John Gillespie and Pip Nicholson (eds.), Asian Socialism and Legal Change: The Dynamics of Vietnamese and Chinese Reform (Asian Pacific Press, 2005), 191.
} 
as $2003,{ }^{120}$ several years before it was celebrated in China. Meanwhile, the CCP is more aggressive at penetrating and controlling organized challenges from the legal profession while the VCP appears relatively more tolerant of their institutional autonomy. Vietnam's National Bar Association has little control over regional and local bar associations, as the latter openly challenge the former's lack of autonomy from the government. ${ }^{121}$ The Ho Chi Minh City Bar Association, in particular, is much more active than its Chinese counterparts in seeking autonomy from regulators and is more responsive to the interests of its members when in conflict with the government. ${ }^{122}$ Of course, whether stronger challenges from better organized lawyers' organizations will directly lead to deeper political reform and a more credible commitment to rule of law is hard to predict.

Both Party-states engage in the arrest and harassment of individual defense lawyers who take on politically sensitive cases. Le Cong Dinh, a Western-trained lawyer who won a major WTO case for Vietnam was imprisoned from 2009 to 2013 and then disbarred for defending dissidents and bloggers. ${ }^{123}$ In 2011, Cu Huy $\mathrm{Ha} \mathrm{Vu}$ was sentenced to seven years in prison for filing lawsuits against the prime minister and defending clients which included a Roman Catholic parish. ${ }^{124}$ But the scale and severity of repression against human rights lawyers in China has been far worse, as amply demonstrated by the 2015 crackdown resulting in criminal conviction and administrative punishment of dozens of lawyers. ${ }^{125}$

\footnotetext{
${ }^{120}$ For a discussion of the aggressive defense against the prosecution of the Godfather of Saigon, see, id. and Sidel, Law and Society, supra note 9, Chapter 7.

121 Bui Thi Bich Lien, "Legal Education and the Legal Profession in Contemporary Vietnam:

Tradition and Modification," Chapter 12 in Gillespie and Chen (2010), 299.

122 Jerome Cohen, "Introduction to Part V" in Gillespie and Chen (2010), 271.

123 "Stifling the Public Sphere: Media and Civil Society in Egypt, Russia, and Vietnam," National Endowment for Democracy.

124 Id.

${ }^{125}$ Fu Hualing, The July $9^{\text {th }}$ (709) Crackdown on Human Rights Lawyers: Legal Advocacy in an Authoritarian State Journal of Contemporary China (forthcoming 2018); and Alex W. Palmer, 'Flee at
} 
The persistent question thus remains whether a Party-state will rely on the formal legal system to resolve disputes according to proper procedures, or resort to repression or other unprincipled informal mechanisms based on political expedience? As numerous studies have shown, unprincipled dispute resolution that bypasses the legal system eventually exacerbates social conflict and becomes a destabilizing factor unto itself. $^{126}$ There is indeed an emerging consensus among political elites that dispute resolution based on the rule of law and predictable legal principles is the most cost-effective way to resolve the vast majority of the cases. ${ }^{127}$

When discourse signals a constitutional commitment on the part of the Party-state, citizens in both nations have responded by seizing that discourse. Constitutional rhetoric gives space for articulation and action by civil society, and has inspired people to fight for them even in authoritarian states. The gap between a high normative standard of constitutional rights and low levels of practical enforcement sharpens the contrast between entitlement and reality, creating further incentives and opportunities for mobilization. It is commonly agreed that rights-awareness has been on the rise steadily with political and legal consequences in both countries, ${ }^{128}$ and aware citizens invariably demand to exercise those rights through available institutions.

Once’: China’s Besieged Human Rights Lawyers, New York Times, 25 July 2017;

https://www.nytimes.com/2017/07/25/magazine/the-lonely-crusade-of-chinas-human-rights-lawyers.ht $\mathrm{ml}$

126 Liangjiang Li, Mingxing Liu and Kelvin J O’Brien, "Petitioning Beijing: The High Tide of 2003-2006," 210 China Quarterly 313-34 (2012); Carl F. Minzner, "Xinfang: Alternative to Formal Chinese Legal Institutions," 42 Stanford J. of Int'l L. 103 (2006); and Yanhua Deng and Kevin. J. O'Brien "Relational Repression in China: Using Social Ties to Demobilize Protesters" 214 China Quarterly 533-52 (2013).

127 Randall Peerenboom, "The Future of Legal Reforms in China: A Critical Appraisal of the Decision on Comprehensively Deepening Reform" available at http://papers.ssrn.com/sol3/papers.cfm?abstract_id=2379161 (last visited 16 Oct. 2015).

128 See, for example, Michael Dowdle, Introduction to Part II, in Gillespie and Chen (2010), 106; Zheng Ge, "Toward Regulatory Neutrality in a Party-state? A Review of Administrative Law Reforms in China," Chapter 5 in Gillespie and Chen (2010), 119; Dang Xuan Hop, "Vietnam: The Past 25 Years, the Present and the Future," E. Ann Black \& Gary F. Bell (eds.), Law and Legal Institutions of Asia: Traditions, Adaptations and Innovations (Cambridge: Cambridge University Press, 2011) 210. 
If those institutions fail to deliver, people will create or resort to non-institutional fora for remedies. Ultimately, the authoritarian Party-state's flirtation with rule of law is a double-edged sword which has been wielded with great caution, mindful of law's inherent threat to authoritarian rule.

\section{Conclusion}

Constitutional rights are alive in people's esteem in both China and Vietnam as grass-root constitutional demands unfold on a daily basis. While judicial construction is severely constrained, citizens actively interpret and implement constitutional rights in forums across both countries including streets, factories, churches and classrooms. This Chapter conceptualized similarities and differences between three substantive foundations of constitutional practices in both states, i.e., the leadership of the communist party, faith in developing a socialist rule of law, and requisite state responsiveness to popular will.

Regime survival is the ultimate goal for any single party which desires to perpetuate its command of power. The Party-state model is adapting to new circumstances and continues to evolve incrementally to develop and defend its credibility and legitimacy. One core strategy is reliance upon legal rules to discipline the state and impose order in society. Ultimately, rule of law is a double-edged sword which the Party-state must wield with great caution, mindful of law's inherent, potential threat to authoritarian rule. While the Party-state purposively maintains a weak legal system to satisfy its own political agenda, a weak system cannot contain the socioeconomic problems it is designed to resolve. Resort to extra-judicial fora undermines the state's legal system while delegating some degree of constitutional enforcement to the people. 
Both constitutional orders are presently locked in a cycle of mobilization and counter-mobilization in which societal forces demand change which the Party-state considers, manages, and occasionally, concedes. This requires the Party to constantly balance its position against popular action pushing for a redistribution of interests or incremental change, while the legal system attempts to impose a degree of regularity. Where civil society is consulted, that process is likely to go more smoothly and with less resistance then in soil where even nascent organized civil society is resisted. The Sino-Vietnamese comparison indicates that the limits of the Chinese experiment with constitutionally-based legal reform over the past several decades seem to have hardened, at least for the time being. While China and Vietnam may share common constraints, the scope for depth of reform appears deeper in Vietnam, whose system currently possesses the advantages of being more open and receptive to new ideas, both internal and external in origin. Thus, the "socialism with Vietnamese characteristics" outlined herein may allow the Vietnamese Party-state to rejuvenate itself while overcoming some of the institutional barriers that have stalled reform in China. 